Agro-Science Journal of Tropical Agriculture. Food, Environment and Extension Volume 3 Number 2. June 2002 pp. 1- 12

ISBN 1119-7455

\title{
CHANGES IN SOME PHYSICAL PROPERTIES OF A TYPIC HAPLORTHOX IN SOUTHERN BRAZIL UNDER NO-TILLAGE CROP ROTATION SYSTEMS
}

\author{
Vieira, S.R. ${ }^{1}$, Mbagwu, J.S.C. ${ }^{2}$, Castro, O.M. de ${ }^{1}$, Alves, M.C. ${ }^{3}$, Dechen, S.C.F. ${ }^{1}$ and \\ De Maria, I.C. ${ }^{1}$
}

1. Centro de Pesquisa e Desenvolvimento de Solos e Recursos Ambientais, Instituto Agronômico (IAC), CP 28, CEP 13001- 970, Campinas SP, Brazil,

Email: sidney@iac.br.

2. Department of Soil Science, University of Nigeria, Nsukka, Nigeria

E-mail joembagwu2003@yahoo.com

3. Faculdade de Engenharia de Ilha Solteira, UNESP, Ilha Solteira, SP, Brazil.

\begin{abstract}
The assessment of the impacts of different crop rotations on soil physical properties is needed to identify those with the potential to improve such properties which enhance crops' responses to soil nutrients. The effects of eight crop rotations on physical properties of a Rhodic Ferralsol (Typic Haplorthox) were assessed in Palmital, Svo Paulo, Brazil, using a randomized complete block design with three replications of each treatment. The study lasted for five years (1985 -1990). The crop rotations, planted during the winter from 1985 to 1987, were mucuna, pigeon pea, rye, oat, pisum, wheat, crotalaria and black oat. In 1988 wheat was planted on all plots and from 1989 to 1990, lathyrus, lupin, rye, oat, lupin + black oat, wheat, crotalaria and black oat were planted. The summer crops were maize and soybean. In all treatments and taking the average of all the soil horizons, lupin+black oat and lathyrus produced the lowest bulk density in both maize and soybean plots. When the ranking of the performance of these crop rotations was performed, the order in the maize plots was lupin+black oat > rye > lathyrus > lupin/wheat $>$ oat $>$ crotalaria/black oat. On soybean plots the order was lathyrus > lupin > lupin+black oat $>$ rye $>$ oat $>$ crotalaria $>$ black oat $>$ wheat. It is evident that for the summer crops, lupin+black oat, rye, lathyrus and lupin were consistent in improving these soil physical properties and are therefore, better than the rest of the rotation crops in moderating these properties. Even though there was low improvement in OM content of the soil, OM moderated very significantly bulk density $(r=0.602 * *)$ and saturated hydraulic conductivity (Ksat) $\left(r=0.674^{* *}\right)$ under soybean plots. However, macro-porosity (Pe) had positive improvement in Ksat $\left(r=0.684^{* *}\right)$ under maize of all the physical properties measured. Longer lasting crop rotations may produce more positive influences of $\mathrm{OM}$ on these soil physical properties.
\end{abstract}

Keywords: Water holding capacity; Aggregate stability; Saturated hydraulic conductivity; Bulk density; Organic matter; Maize; Soybean. 


\section{INTRODUCTION}

The introduction of no-tillage crop rotation systems started in Brazil in the '70's when the high cost of fertilizers necessitated curtailing their use on farmlands (FAO, 2000). The idea was to increase the organic matter (OM) levels and their associated nutrients in soils by utilizing the biomass produced by the rotation crops. Other than the release of nutrients by the decomposing biomass, additional benefits from these rotations were stabilization of surface soil temperature, improvement in soil water holding capacity, infiltration and saturated hydraulic conductivity, enhancing aggregate stability and to some extent in reducing bulk density and penetration resistance in soils (Corsini, 1991; Lal, 1974; Lal and Stewart, 1990; Christensen and Johnston, 1997). The interest in physical properties of soils is predicated on the fact that they influence crop responses to chemical fertilizers in soils, especially in tropical and subtropical regions. This is so because crop responses to nutrient levels in soils are moderated by the physical status of the soil. Some of the soil physical constraints to crop production in the tropical and sub-tropical regions are proneness to erosion by water or wind, low available water-holding capacity and increased subsoil compaction. This compaction is caused by conventionally tilling the soil to a particular depth and consolidation of dispersed clay particles, which move down to the subsurface horizons. Others are low movement of water into and within the soils, especially in the soils of subtropical regions, which are prone to dispersion (Bouma and Hole, 1971; Fernández-Reuda and Paz-González, 1998; Kay, 1990; Mc Farlane et al., 1992).

One of the reasons for the poor physical state of these soils is their low organic matter (OM) content and several researchers have tried to develop ways to increase the OM levels in soils so as to improve their physical conditions. Under intensive crop production systems found in Brazil the combination of different tillage and crop rotation systems have been investigated and it appears that the no-tillage system is very promising in increasing and sustaining crop production. However, the choice of winter crops for rotation with summer crops in the no-tillage system has not been resolved yet (Alves et al., 1994; Dechen et al., 1988).

In Brazil and elsewhere in the tropics, increased water entry into the soil, reduced bulk density and penetrometer resistance, and enhanced water holding capacity of soils are some of the advantages of using no-tillage with crop rotations (Lal, 1998; Mbagwu, 1990: Dechen et al., 1988; Alves et al., 1994: Kemper and Derpsch, 1981). All these improvements have been linked to high OM contents of the treated soils. The objective of this study is to evaluate eight crop rotation systems in southern Brazil for their ability to improve some physical properties of a Rhodic Ferralsol (Typic Haplorthox) as well as to examine the relationship between such improvements and the organic matter levels of the soil.

\section{MATERIALS AND METHODS}

Location and climate of the study site: This study was conducted at a private farm near Palmital, São Paulo, southern Brazil, for five years $(1985$ - 1990). The coordinates of the location are latitude $24^{\circ} 47^{\prime} \mathrm{S}$ and longitude $50^{\circ}$ $13^{\prime} \mathrm{W}$, at $500 \mathrm{~m}$ height asl. The warm and wet season here is from October to March, which area has a mean temperature of 18 to $22^{0} \mathrm{C}$, average total precipitation of $1280 \mathrm{~mm} \mathrm{y}^{-1}$ and relative humidity of $70 \%$. The dry season is from April to September, with a mean temperature of $25^{\circ} \mathrm{C}$ and total precipitation of $350 \mathrm{~mm}$ during the year (Köppen, 1936; Ortolani et al., 1995). Beginning from 1980, the experimental area was grown to soybean in the summer and wheat in the winter for five years under no-tillage system before initiating this study in 1985. The soil is a Rhodic Ferralsol (FAO/UNESCO system) or Typic Haplorthox (Soil Taxonomy), and the initial topsoil physical properties were $5 \mathrm{~g} \mathrm{~kg}^{-1}$ sand, $24 \mathrm{~g} \mathrm{~kg}^{-1}$ silt and $71 \mathrm{~g} \mathrm{~kg}^{-1}$ clay, bulk density, $1.13 \mathrm{~g} \mathrm{~cm}^{-3}$, total porosity \{calculated as 1- [dry bulk density/particle density, where particle density is assumed to be $\left.\left.2.65 \mathrm{~g} \mathrm{~cm}^{-3}\right]\right\}, 57.4 \%$, macroporosity, $22.4 \%$, and micro-porosity, $35.0 \%$. The water retained at saturation was $60 \%$ and at 
$-2,-6,-10,-30,-70,-100$ and $-1500 \mathrm{kPa}$ were respectively, 46, 39, 39, 35, 33, 32 and $22 \%$.

Treatments: In 1985 a study with eight crop rotation systems, and two summer crops: maize (Zea mays L.) and soybean (Glycine max L.) was initiated. The eight winter treatments which lasted until 1987, were as follow:

$\begin{array}{ll}\text { a. } & \text { Mucuna: (Mucuna aterrima Piper \& } \\ \text { b. } & \text { Tracy) } \\ \text { c. } & \text { Pigeon pea (Cajanus cajan (L.) Millsp) } \\ \text { d. } & \text { Rye (Secale cereale L.) } \\ \text { e. } & \text { Oat (Avena sativa L.) } \\ \text { f. } & \text { Ervilhaca (Lathyrus sativus L.) } \\ \text { g. } & \text { Wheat (Triticum aestivum L.) } \\ \text { h. } & \text { Crotalaria (Crotalaria juncea L.) } \\ \text { i. } & \text { Black oat (Avena strigosa } \text { Schieb) }\end{array}$

In 1988 wheat was planted on all the plots because of low dry matter yields of the winter crops in 1986 and 1987 but from 1989 to 1990 the following winter crops were used:

a. Ervilhaca (Lathyrus sativus L.)

b. Lupin (Lupinus albus L.)

c. $\quad$ Rye (Secale cereale L.)

d. Oat (Avena sativa L.) Lupin + Black oat (Lupinus albus L. + Avena strigosa Schieb)Wheat (Wheat, Triticum aestivum L.)

e. Crotalaria (Crotalaria juncea L.)

f. Black oat (Avena strigosa Schieb).

Conventional spacing and cultural practices were adopted throughout this study. Each year fertilizer was applied at the rate of $70 \mathrm{~kg} \mathrm{ha}^{-1} \mathrm{P}$ and $50 \mathrm{~kg} \mathrm{ha}^{-1} \mathrm{~K}$ for soybean and $102 \mathrm{~kg} \mathrm{ha}^{-1} \mathrm{~N}$, $50 \mathrm{~kg} \mathrm{ha}^{-1} \mathrm{P}$ and $50 \mathrm{~kg} \mathrm{ha}^{-1} \mathrm{~K}$ for maize. Twothirds of the $\mathrm{N}$ fertilizer was applied at planting and one-third four weeks after germination. These are the commonly used rates by farmers in this area. The granular fertilizers were placed in the groove opened by a double-disk opener, 5-10 $\mathrm{mm}$ from the seeds. Nitrogen was applied as ammonium sulphate, $\mathrm{P}$ as single superphosphate and $\mathrm{K}$ as potassium chloride. Weeds were controlled by pre- and post- emergence herbicides.
Experimental set up: The set up of the experiment was a randomized complete block design in which each of the eight treatments was replicated three times. Each treatment covered an area of $96 \mathrm{~m}^{2}$. A distance of $2 \mathrm{~m}$ separated two treatments and a distance of $10 \mathrm{~m}$ separated the replicates. The total area of the experiment was $4,368 \mathrm{~m}^{2}$.

Soil sampling and analysis: Soil samples were collected from all plots after harvest of summer crops in 1990 for evaluating any changes in soil physical properties due to the crop rotations. For the determination of bulk density, porosity, pore size distribution and water retention curve, undisturbed soil samples were taken with cores of $0.05 \mathrm{~m}$ internal diameter and $0.051 \mathrm{~m}$ height, at four depths $(0-0.05,0.05-0.10,0.10-0.20$ and $0.20-0.30 \mathrm{~m})$. Bulk density was calculated by the method of Blake and Hartge (1986a). Total soil porosity was determined by the method of Danielsen and Sutherland (1986) using the relationship between soil bulk and particle densities (Blake and Hartge, 1986b). Macroporosity was calculated using the following relationship $F_{a}=\left(\theta_{s}-\theta_{m}\right) \times 100 \ldots$ (1)

where $\mathrm{Fa}$ is macro-porosity (\%), $\theta$ s is total porosity $\left(\mathrm{cm}^{3} \mathrm{~cm}^{-3}\right)$, calculated from bulk and particle densities relationships indicated above and $\theta \mathrm{m}$ is volumetric moisture retained at -10 $\mathrm{kPa}$ matric potential $\left(\mathrm{cm}^{3} \mathrm{~cm}^{-3}\right)$. Micro-porosity was determined as the difference between total porosity and macro-porosity.

Soil water retention was measured by the method of Klute (1986) at 0 and $-2,-6,-10,-30$, $-70,-100$ and $-1500 \mathrm{kPa}$ matric potentials. The $0,-2$ and $-6 \mathrm{kPa}$ matric potentials were measured with a tension table and potentials -10 $\mathrm{kPa}$ and above were measured with a pressure plate apparatus (Topp and Zebchuk, 1979; Ball and Hunter, 1988). The available water holding capacity (AWC) was integrated for the four horizons in a treatment using the following equation:

$$
A W C=\sum_{\mathrm{i}=1}^{\mathrm{n}}\left\{\left(\theta_{i 10}-\theta_{i 1500}\right) x D i\right\} \ldots
$$

where $\mathrm{AWC}$ is in $\mathrm{cm}, \theta_{\mathrm{i} 10}$ is the volumetric water retained in the ith horizon at $-10 \mathrm{kPa}$ 
matric potential $\left(\mathrm{cm}^{3} / \mathrm{cm}^{3}\right), \quad \theta_{\mathrm{i} 1500}$ is the volumetric water retained in the ith horizon at $1500 \mathrm{kPa}$ matric potential $\left(\mathrm{cm}^{3} / \mathrm{cm}^{3}\right)$, Di is the horizon depth $(\mathrm{cm})$ and $\mathrm{i}$ varies from 1 to 4 . This integration produced one value per treatment, which enabled us to make a valid assessment of the contributions of crop rotation systems to the AWC of the soil.

Aggregate stability was measured at 0-5, 5-15, and $15-30 \mathrm{~cm}$ depths with disturbed soil samples. These samples were air-dried and sieved through a 9.52-mm sieve diameter. The $<$ $9.52 \mathrm{~mm}$ aggregates were then placed on the topmost of a nest of sieves of diameters 7.63, $6.35,4.00,2.00,1.00$ and $0.50 \mathrm{~mm}$ and agitated in water following the methods of Kemper and Rosenau (1986). Care was taken to ensure that all aggregates were below the water surface during agitation in water. An amplitude of 3.7 $\mathrm{cm}$ was used and each sieving was completed after $10 \mathrm{~min}$ at 29 times/min. Thereafter, each aggregate remaining on each sieve and the one that passed through the $0.50 \mathrm{~mm}$ mesh were dried in the oven at $105^{\circ} \mathrm{C}$ for $24 \mathrm{~h}$ and weighed. Since the sand fraction on the soil samples was low no correction for sand was made in this analysis. The proportion of water-stable aggregates on each sieve size fraction was then calculated from:

$$
W S A=\left(W_{2 i}-W_{3 i}\right) /\left(\left(W_{1} /\left(1+W_{c}\right)\right)-W_{3 i} \ldots(3)\right.
$$

where $\mathrm{i}=1,2,3, \ldots, \mathrm{n}$ and corresponds to each size fraction. These WSA values were used to calculate the mean-weight diameter (MWD), an index of aggregate stability thus:

$\mathrm{n}$

$$
M W D=\sum_{\mathrm{i}=1}\left(X_{i}^{*} W S A_{i}\right) \ldots \text { (4) }
$$

where $\mathrm{i}=1,2,3, \ldots, \mathrm{n}$ and corresponds to each fraction collected, including the one that passed the finest $(0.05 \mathrm{~mm})$ sieve; $X_{i}$ is the mean diameter of each size fraction (i.e., mean intersieve size); and $\mathrm{WSA}_{\mathrm{i}}$ is as defined in Equation 3 (Angers and Mehuys, 1993). The higher the MWD of a soil sample the better its stability in water.

Saturated hydraulic conductivity (Ksat) was measured at two depths (0-15 and $15-30 \mathrm{~cm})$ with the Guelph permeameter technique (Reynolds and Elrick, 1987; Klute and Dirksen, 1986) and calculated using the transposed Darcy's equation for vertical flows of liquids thus:

$$
\text { Ksat }=(4 Q L) /\left(\pi \mathrm{tHd}_{\mathrm{c}}{ }^{2}\right) . .
$$

where Ksat is saturated hydraulic conductivity $(\mathrm{cm} / \mathrm{s})$; Q $(\mathrm{mL})$ is the volume of water collected during time interval, $\mathrm{t}(\mathrm{s})$; $\mathrm{L}$ is the length of the sample core $(\mathrm{m}) ; \mathrm{H}$ is the difference in levation between the water level in the reference tube and the water level in the side arm of the outflow dripper $(\mathrm{cm})$; and $d_{c}$ is the inside diameter of the core $(\mathrm{cm})$. Five determinations of Ksat were made/plot.

Organic matter was determined on the disturbed samples by oxidizing $1 \mathrm{~cm}^{3}$ of soil with a $4 \mathrm{~N}$ sodium dichromate solution and 10 $\mathrm{N}$ sulphuric acid. The amount of $\mathrm{OM}$ was evaluated by colorimetric method and the results obtained from a standard curve of a series of soils in which OM was determined by the Walkley and Black method.

These soil physical data were analyzed as a randomized complete block design using analysis of variance and $F$-test procedure. Where the $F$-tests were significant at $\mathrm{p}<0.05$, comparisons among treatment means was made using the least significant differences (LSD) test (Snedecor and Cochran, 1976).

\section{RESULTS AND DISCUSSION}

The focus of this study is to identify some winter cover crops that can be used in crop rotation systems in southern Brazil to optimize soil physical properties. The extent to which any of these cover crops optimizes the soil physical properties is the extent to which its use as a cover crop is suggested. Hence what is being investigated here is which cover crops improved soil physical properties most. For ease of presentation, the cover crops existing in 1990, when the soil samples for physical measurements were taken, will be used.

Effects of crop rotation on soil bulk density and pore size distribution: The impact of crop rotation on soil bulk density (Table 1) for maize 
and soybean indicates generally higher values and wider variations $(\mathrm{CV} \%)$ in soybean $(3.1 \%)$ than in maize $(2.9 \%)$ plots.

Table 1. Effects of crop rotations on bulk density of a Ferralsol under maize and soybean plots in southern Brazil.

\begin{tabular}{lccccc}
\hline \multirow{2}{*}{ Crops/Treatments } & \multicolumn{5}{c}{ Profile depths (cm) } \\
\cline { 2 - 6 } & $\mathbf{0 - 5}$ & $\mathbf{5 - 1 0}$ & $\mathbf{1 0 - 2 0}$ & $\mathbf{2 0 - 3 0}$ & Means \\
\hline Lupinus+Black oat & 1.12 & 1.10 & 1.08 & 1.04 & 1.09 \\
Lupinus & 1.14 & 1.15 & 1.23 & 1.16 & 1.17 \\
Rye & 1.04 & 1.11 & 1.15 & 1.01 & 1.08 \\
Oat & 1.12 & 1.13 & 1.24 & 1.09 & 1.15 \\
Lathyrus & 1.08 & 1.15 & 1.10 & 1.04 & 1.09 \\
Wheat & 1.14 & 1.15 & 1.10 & 1.08 & 1.12 \\
Crotolaria & 1.14 & 1.17 & 1.17 & 1.07 & 1.14 \\
Black oat & 1.09 & 1.19 & 1.20 & 1.07 & 1.14 \\
LSD (0.05): Trts (T): & 0.03 & & & & \\
Depth (D): & 0.17 & & & & \\
TxD: & 0.08 & & & & \\
& Soybean & & & \\
Lupinus+Black oat & 1.12 & 1.14 & 1.13 & 1.06 & 1.11 \\
Lupinus & 1.16 & 1.22 & 1.16 & 1.10 & 1.16 \\
Rye & 1.07 & 1.21 & 1.23 & 1.13 & 1.16 \\
Oat & 0.99 & 1.14 & 1.26 & 1.13 & 1.13 \\
Lathyrus & 1.06 & 1.13 & 1.18 & 1.06 & 1.11 \\
Wheat & 1.15 & 1.25 & 1.26 & 1.17 & 1.20 \\
Crotolaria & 1.19 & 1.24 & 1.23 & 1.14 & 1.20 \\
Black oat & 1.14 & 1.21 & 1.23 & 1.11 & 1.17 \\
LSD (0.05): Trts (T): & 0.04 & & & & \\
Depth (D): & 0.15 & & & & \\
TxD: & 0.12 & & & & \\
\hline
\end{tabular}

The variations were, however, rather low and confirm the results of Mbagwu (1995) among others, of smaller variation in bulk density $(11.7 \%)$ than in hydraulic properties $(70.6-125.2 \%)$ of tropical soils. Under maize the highest soil bulk density was obtained with lupin $\left(1.17 \mathrm{~g} \mathrm{~cm}^{-3}\right)$ followed by rye $\left(1.15 \mathrm{~g} \mathrm{~cm}^{-}\right.$ 3) whereas the least values $\left(1.09 \mathrm{~g} \mathrm{~cm}^{-3}\right)$ occurred in lupin+black oat and lathyrus. Under soybean the highest soil bulk density values occurred in wheat $\left(1.26 \mathrm{~g} \mathrm{~cm}^{-3}\right)$ and crotalaria $\left(1.24 \mathrm{~g} \mathrm{~cm}^{-3}\right)$ and the least with lathyrus $(1.06 \mathrm{~g}$ $\left.\mathrm{cm}^{-3}\right)$ and lupin+black oat $\left(1.06 \mathrm{~g} \mathrm{~cm}^{-3}\right)$. It is evident therefore, that in both crops the rotations that optimized soil bulk density are lupin+black oat and lathyrus. Also, lupin+black oat and lathyrus produced the highest values in total porosity in soybean whereas rye and lupin+black oat followed very closely by lathyrus produced the highest values in maize (Table 2).
Table 2. Effects of crop rotations on total porosity of a Ferralsol (\%) under maize and soybean plots in southern Brazil.

\begin{tabular}{|c|c|c|c|c|c|}
\hline \multirow[t]{2}{*}{ Crops/Treatments } & \multicolumn{5}{|c|}{ Profile depths (cm) } \\
\hline & $0-5$ & $5-10$ & $10-20$ & $20-30$ & Means \\
\hline \multicolumn{6}{|c|}{ Maize } \\
\hline Lupinus+Black oat & 57.7 & 58.5 & 59.2 & 59.6 & 58.8 \\
\hline Lupinus & 57.0 & 56.6 & 53.6 & 56.2 & 55.9 \\
\hline Rye & 60.8 & 58.1 & 56.6 & 61.9 & 59.4 \\
\hline Oat & 57.7 & 57.4 & 53.2 & 58.9 & 56.8 \\
\hline Lathyrus & 59.2 & 56.6 & 58.5 & 59.6 & 58.5 \\
\hline Wheat & 57.0 & 56.6 & 58.5 & 59.2 & 57.8 \\
\hline Crotolaria & 57.0 & 52.5 & 52.5 & 59.6 & 55.4 \\
\hline Black oat & 58.9 & 55.1 & 54.7 & 59.6 & 57.1 \\
\hline LSD (0.05): Trts (T): & 2.2 & & & & \\
\hline Depth (D): & 6.1 & & & & \\
\hline TxD: & 5.0 & & & & \\
\hline \multicolumn{6}{|c|}{ Soybean } \\
\hline Lupinus+Black oat & 57.7 & 57.0 & 57.4 & 60.0 & 58.0 \\
\hline Lupinus & 56.2 & 54.0 & 56.2 & 58.5 & 56.2 \\
\hline Rye & 59.6 & 54.3 & 53.4 & 57.4 & 56.2 \\
\hline Oat & 62.6 & 57.0 & 52.5 & 57.4 & 57.4 \\
\hline Lathyrus & 60.0 & 57.4 & 55.4 & 60.0 & 58.2 \\
\hline Wheat & 56.6 & 53.6 & 52.5 & 55.8 & 54.6 \\
\hline Crotolaria & 55.1 & 53.2 & 53.6 & 57.0 & 54.7 \\
\hline Black oat & 57.0 & 54.3 & 53.6 & 58.1 & 55.8 \\
\hline LSD (0.05): Trts (T): & 1.3 & & & & \\
\hline Depth (D): & 7.9 & & & & \\
\hline TxD: & 6.3 & & & & \\
\hline
\end{tabular}

The association of lupin (a legume) and black oat (a grass) appears to produce an ideal soil environment for optimizing soil bulk density during maize production of the total porosity values, the microporosity was higher than the macro-porosity.

Table 3. Effects of crop rotations on macro-porosity of a Ferralsol (\%) under maize and soybean plots in southern Brazil.

\begin{tabular}{|c|c|c|c|c|c|}
\hline \multirow[t]{2}{*}{ Crops/Treatments } & \multicolumn{5}{|c|}{ Profile depths (cm) } \\
\hline & $0-5$ & $5-10$ & $10-20$ & $20-30$ & Means \\
\hline \multicolumn{6}{|c|}{ Maize } \\
\hline Lupinus+Black oat & 17.0 & 17.5 & 19.9 & 21.5 & 19.0 \\
\hline Lupinus & 18.1 & 16.3 & 11.3 & 16.9 & 15.7 \\
\hline Rye & 23.0 & 19.2 & 16.3 & 23.9 & 20.6 \\
\hline Oat & 17.7 & 17.8 & 10.7 & 20.6 & 16.7 \\
\hline Lathyrus & 20.9 & 15.1 & 18.4 & 21.1 & 18.9 \\
\hline Wheat & 16.9 & 16.1 & 20.9 & 19.8 & 18.4 \\
\hline Crotalaria & 18.4 & 13.0 & 12.9 & 21.2 & 16.4 \\
\hline Black oat & 21.7 & 13.8 & 13.4 & 27.1 & 17.8 \\
\hline $\operatorname{LSD}(0.05):$ Trts $(\mathrm{T}):$ & 2.9 & & & & \\
\hline Depth (D): & 6.1 & & & & \\
\hline TxD: & 4.3 & & & & \\
\hline \multicolumn{6}{|c|}{ Soybean } \\
\hline Lupinus+Black oat & 19.0 & 19.4 & 17.2 & 21.4 & 19.3 \\
\hline Lupinus & 15.3 & 12.4 & 15.4 & 19.4 & 15.6 \\
\hline Rye & 21.7 & 13.8 & 11.2 & 16.7 & 15.9 \\
\hline Oat & 26.1 & 18.4 & 10.9 & 19.8 & 18.8 \\
\hline Lathyrus & 22.3 & 18.8 & 13.9 & 20.1 & 18.9 \\
\hline Wheat & 15.4 & 11.1 & 9.6 & 14.7 & 12.7 \\
\hline Crotalaria & 13.2 & 11.8 & 12.1 & 16.9 & 13.5 \\
\hline Black oat & 17.9 & 14.0 & 12.9 & 18.8 & 15.9 \\
\hline LSD (0.05): Trts (T): & 4.6 & & & & \\
\hline Depth (D): & 9.2 & & & & \\
\hline TxD: & 7.8 & & & & \\
\hline
\end{tabular}


Table 4. Effects of crop rotations on micro-porosity of a Ferralsol (\%) under maize and soybean plots in southern Brazil.

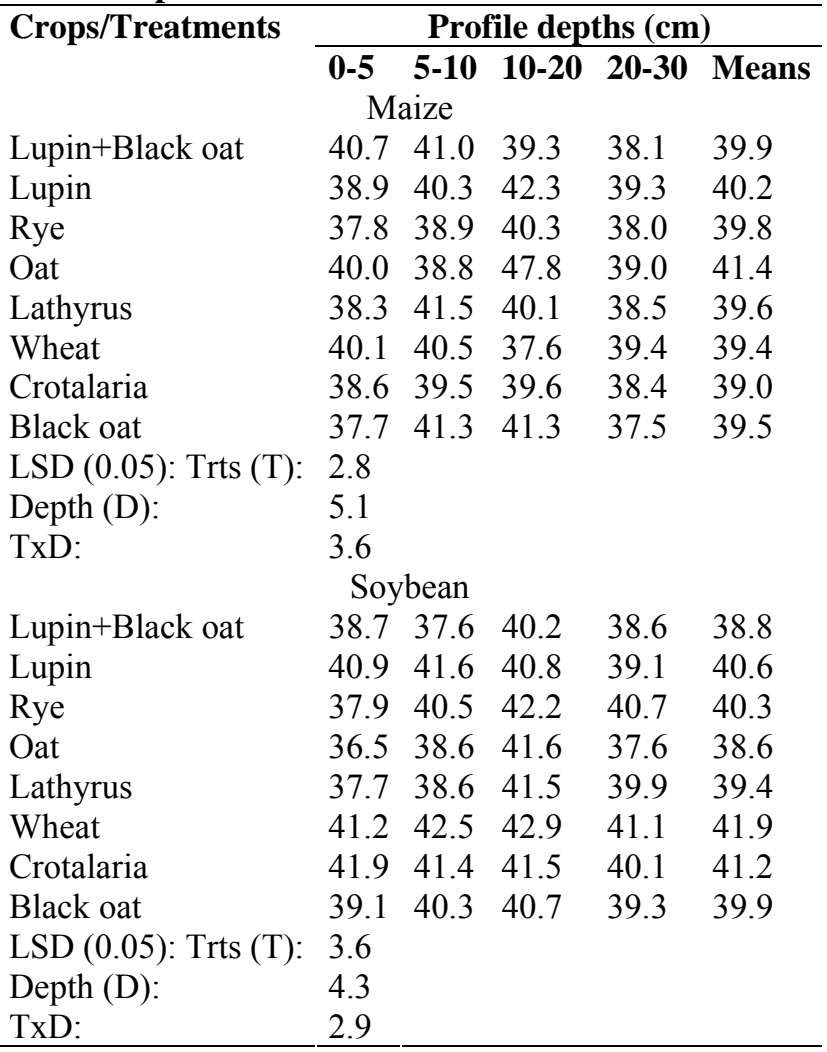

The micro-porosity here includes all pore spaces draining between -100 and $-6 \mathrm{kPa}$ potentails but did not include those draining between -1500 and $-100 \mathrm{kPa}$ potentials. The macro-porosity values were rather low (Table 3) and varied between 10.5 and $16.8 \%$ in maize plots and between 9.6 and $15.5 \%$ in soybean plots. Hence these rotations reduced the macroporosity but increased the micro-porosity of this soil slightly. Mbagwu (1995), Ahuja et al.
(1989), Franzmeier (1991) and Carter (1988) had shown the positive contribution of macropores to water movement within the soil and also the fact that it is affected easily by land use. Bouma (1991) also noted that it is mainly through macro-pores that water moved down to contaminate ground water. Taking the average of the four horizons, the three best crop rotations that optimized the macro-orosity of the maize plots were rye $>$ lupin+black oat $>$ lathyrus and of the soybean plots, oat $>$ lupin+black oat $>$ lathyrus.

The micro-porosity values (Table 4) were large and could be responsible for the fairly low water movement within the soil. There was also no consistent pattern of their distribution within the soil. They varied between 42.5 and $43.7 \%$ in the maize plots and between 42.0 and $45.1 \%$ in the soybean plots, implying small variability of $1.1 \%$ in maize and $2.5 \%$ in soybean plots. Mbagwu (1995) obtained wider variations in these properties than the ones got from this study, even though he worked mainly with Ultisols and Entisols. Considering that the lower the values of this property the better the improvement of the rotation crops, it is seen here that for maize crops the best three rotations are crotalaria $>$ wheat $>$ lathyrus and for soybean, oat $>$ lupin + black oat $>$ black oat.

Effects of crop rotation on soil water retention properties: The soil water content and available water holding capacity data are shown in Table 5 for maize and in Table 6 for soybean. 
Vieira, S.R., Mbagwu, J.S.C., Castro, O.M. de, Alves, M.C., Dechen, S.C.F. and De Maria, I.C.

Table 5. Water content (\%) and available water holding capacity (cm) of a Ferralsol under maize in southern Brazil.

\begin{tabular}{|c|c|c|c|c|c|c|c|c|c|c|}
\hline \multirow[t]{2}{*}{ Treatments } & \multirow{2}{*}{$\begin{array}{l}\text { Depths } \\
\text { (cm) }\end{array}$} & \multicolumn{9}{|c|}{ Moisture retained at different matric potentials (KPa) } \\
\hline & & $\mathbf{0}$ & -2 & -6 & -10 & -30 & -70 & -100 & -1500 & AWC \\
\hline \multirow{4}{*}{$\begin{array}{l}\text { Lupin+Black } \\
\text { oat }\end{array}$} & $0-0.05$ & 57.7 & 51.8 & 44.2 & 40.7 & 35.4 & 33.0 & 30.8 & 19.7 & 5.45 \\
\hline & $0.05-0.10$ & 56.3 & 51.8 & 43.9 & 39.5 & 35.1 & 32.9 & 31.3 & 19.6 & \\
\hline & $0.10-0.20$ & 58.7 & 48.6 & 40.6 & 37.5 & 31.9 & 30.3 & 29.4 & 20.6 & \\
\hline & $0.20-0.30$ & 59.2 & 50.2 & 42.5 & 38.5 & 32.9 & 30.6 & 29.5 & 21.2 & \\
\hline \multirow[t]{4}{*}{ Lupin } & $0-0.05$ & 58.4 & 50.5 & 43.2 & 38.9 & 33.1 & 31.0 & 29.8 & 20.0 & 6.13 \\
\hline & $0.05-0.10$ & 57.6 & 51.0 & 44.0 & 40.3 & 35.0 & 32.7 & 30.6 & 19.7 & \\
\hline & $0.10-0.20$ & 56.4 & 50.4 & 45.1 & 42.3 & 38.1 & 36.2 & 34.9 & 19.2 & \\
\hline & $0.20-0.30$ & 60.7 & 48.8 & 42.3 & 39.3 & 34.7 & 33.2 & 32.2 & 20.9 & \\
\hline \multirow[t]{4}{*}{ Rye } & $0-0.05$ & 60.0 & 50.1 & 41.5 & 37.8 & 31.6 & 29.2 & 27.9 & 21.6 & 5.43 \\
\hline & $0.05-0.10$ & 59.6 & 52.6 & 43.2 & 38.9 & 32.8 & 31.2 & 29.9 & 20.8 & \\
\hline & $0.10-0.20$ & 56.7 & 50.3 & 43.5 & 40.3 & 35.0 & 33.0 & 31.9 & 10.9 & \\
\hline & $0.20-0.30$ & 60.6 & 52.2 & 42.1 & 38.0 & 31.8 & 29.4 & 28.3 & 22.2 & \\
\hline \multirow[t]{4}{*}{ Oat } & $0-0.05$ & 57.5 & 49.7 & 43.3 & 40.0 & 33.7 & 31.2 & 30.2 & 19.6 & 6.38 \\
\hline & $0.05-0.10$ & 57.1 & 48.3 & 43.4 & 39.6 & 34.0 & 32.2 & 30.8 & 19.3 & \\
\hline & $0.10-0.20$ & 54.8 & 51.4 & 45.6 & 42.5 & 38.0 & 36.2 & 35.3 & 17.2 & \\
\hline & $0.20-0.30$ & 58.1 & 50.9 & 41.4 & 38.3 & 33.1 & 31.3 & 30.6 & 20.2 & \\
\hline \multirow[t]{4}{*}{ Lathyrus } & $0-0.05$ & 57.8 & 49.7 & 42.3 & 38.3 & 32.2 & 30.2 & 29.1 & 20.0 & 6.23 \\
\hline & $0.05-0.10$ & 56.3 & 51.9 & 45.3 & 41.5 & 35.9 & 33.5 & 31.9 & 18.7 & \\
\hline & $0.10-0.20$ & 57.1 & 51.5 & 44.0 & 40.1 & 34.4 & 32.6 & 31.5 & 19.0 & \\
\hline & $0.20-0.30$ & 58.9 & 50.1 & 42.2 & 38.5 & 33.2 & 31.3 & 30.3 & 21.0 & \\
\hline \multirow[t]{4}{*}{ Wheat } & $0-0.05$ & 57.4 & 51.0 & 43.5 & 40.1 & 33.9 & 32.1 & 30.9 & 19.5 & 5.85 \\
\hline & $0.05-0.10$ & 56.1 & 52.1 & 45.7 & 40.5 & 37.5 & 36.0 & 33.8 & 18.6 & \\
\hline & $0.10-0.20$ & 57.5 & 49.6 & 42.1 & 39.2 & 34.1 & 33.5 & 32.5 & 18.3 & \\
\hline & $0.20-0.30$ & 59.8 & 50.1 & 42.9 & 39.4 & 33.8 & 32.2 & 30.5 & 21.2 & \\
\hline \multirow[t]{4}{*}{ Crotalaria } & $0-0.05$ & 57.9 & 50.4 & 42.5 & 38.6 & 35.6 & 31.2 & 30.3 & 19.7 & 5.77 \\
\hline & $0.05-0.10$ & 57.0 & 51.3 & 43.7 & 39.5 & 33.5 & 32.3 & 30.7 & 19.0 & \\
\hline & $0.10-0.20$ & 56.5 & 48.4 & 42.4 & 39.6 & 34.5 & 33.0 & 31.9 & 18.7 & \\
\hline & $0.20-0.30$ & 59.8 & 50.1 & 42.5 & 38.4 & 32.4 & 30.5 & 29.5 & 21.3 & \\
\hline \multirow[t]{4}{*}{ Black oat } & $0-0.05$ & 58.1 & 48.1 & 40.9 & 37.7 & 32.0 & 30.1 & 29.3 & 20.2 & 6.20 \\
\hline & $0.05-0.10$ & 55.0 & 50.7 & 43.9 & 41.3 & 35.0 & 32.9 & 32.1 & 17.7 & \\
\hline & $0.10-0.20$ & 55.9 & 51.1 & 43.7 & 41.3 & 37.6 & 35.6 & 33.7 & 18.1 & \\
\hline & $0.20-0.30$ & 55.9 & 51.0 & 41.3 & 37.5 & 32.0 & 30.2 & 29.4 & 19.3 & \\
\hline
\end{tabular}

Table 6. Water content (\%) and available water holding capacity $(\mathrm{cm})$ of a Ferralsol under soybean in southern Brazil.

\begin{tabular}{|c|c|c|c|c|c|c|c|c|c|c|}
\hline \multirow[t]{3}{*}{ Treatments } & \multirow{3}{*}{$\begin{array}{l}\text { Depths } \\
\text { (m) }\end{array}$} & \multicolumn{9}{|c|}{ Water content at different matric potentials (KPa), \% } \\
\hline & & $\mathbf{0}$ & -2 & -6 & -10 & -30 & -70 & -100 & -1500 & AWC \\
\hline & & & & & & & & & & (cm) \\
\hline & $0-0.05$ & 57.2 & 48.9 & 42.6 & 38.7 & 32.8 & 31.0 & 29.9 & 19.5 & 5.44 \\
\hline \multirow{3}{*}{ Lupin+ Black oat } & $0.05-0.10$ & 55.0 & 47.3 & 40.8 & 37.6 & 32.3 & 31.1 & 30.1 & 19.4 & \\
\hline & $0.10-0.20$ & 58.2 & 50.0 & 44.0 & 40.2 & 35.3 & 33.8 & 32.8 & 21.0 & \\
\hline & $0.20-0.30$ & 60.3 & 50.7 & 42.8 & 38.6 & 32.8 & 31.2 & 29.9 & 22.1 & \\
\hline \multirow{4}{*}{ Lupin } & $0-0.05$ & 57.1 & 51.0 & 44.7 & 40.9 & 34.1 & 31.9 & 30.9 & 20.5 & 6.05 \\
\hline & $0.05-0.10$ & 54.6 & 50.6 & 45.4 & 41.6 & 36.1 & 34.2 & 33.3 & 19.2 & \\
\hline & $0.10-0.20$ & 56.7 & 49.5 & 43.9 & 40.8 & 37.1 & 36.2 & 32.7 & 20.3 & \\
\hline & $0.20-0.30$ & 57.2 & 50.5 & 43.3 & 39.1 & 34.5 & 32.3 & 31.3 & 20.5 & \\
\hline \multirow[t]{4}{*}{ Rye } & $0-0.05$ & 58.1 & 50.2 & 41.8 & 37.9 & 31.6 & 29.4 & 28.3 & 21.0 & 6.28 \\
\hline & $0.05-0.10$ & 53.6 & 50.2 & 44.4 & 40.5 & 36.3 & 34.2 & 32.5 & 18.7 & \\
\hline & $0.10-0.20$ & 55.5 & 48.1 & 45.0 & 42.2 & 37.0 & 35.2 & 34.2 & 19.7 & \\
\hline & $0.20-0.30$ & 57.6 & 48.2 & 44.6 & 40.7 & 34.6 & 32.7 & 31.8 & 20.7 & \\
\hline \multirow[t]{4}{*}{ Oat } & $0-0.05$ & 59.9 & 48.4 & 40.2 & 36.5 & 30.9 & 29.2 & 28.2 & 21.9 & 5.77 \\
\hline & $0.05-0.10$ & 53.3 & 50.0 & 42.7 & 38.6 & 33.4 & 32.0 & 30.4 & 18.5 & \\
\hline & $0.10-0.20$ & 54.5 & 49.5 & 44.3 & 41.6 & 36.8 & 35.2 & 34.3 & 19.1 & \\
\hline & $0.20-0.30$ & 55.7 & 49.0 & 40.9 & 37.6 & 32.5 & 30.7 & 30.0 & 19.8 & \\
\hline \multirow[t]{4}{*}{ Lathyrus } & $0-0.05$ & 58.6 & 50.1 & 42.0 & 37.7 & 31.3 & 29.3 & 28.2 & 21.2 & 5.46 \\
\hline & $0.05-0.10$ & 56.5 & 50.9 & 43.4 & 38.6 & 33.6 & 31.4 & 29.9 & 20.2 & \\
\hline & $0.10-0.20$ & 56.7 & 51.1 & 44.9 & 41.5 & 35.6 & 34.6 & 32.9 & 20.3 & \\
\hline & $0.20-0.30$ & 58.8 & 51.6 & 43.7 & 39.9 & 33.2 & 30.8 & 29.8 & 21.3 & \\
\hline \multirow[t]{4}{*}{ Wheat } & $0-0.05$ & 56.1 & 50.4 & 44.3 & 41.2 & 35.1 & 32.7 & 31.1 & 20.0 & 6.44 \\
\hline & $0.05-0.10$ & 54.3 & 51.5 & 46.1 & 42.5 & 37.8 & 35.0 & 33.3 & 19.0 & \\
\hline & $0.10-0.20$ & 54.5 & 50.2 & 45.4 & 42.9 & 37.9 & 36.2 & 34.8 & 19.0 & \\
\hline & $0.20-0.30$ & 56.7 & 50.5 & 44.5 & 41.1 & 36.0 & 36.3 & 32.9 & 20.3 & \\
\hline \multirow{4}{*}{ Crotalaria } & $0-0.05$ & 57.5 & 51.1 & 45.4 & 41.9 & 35.5 & 33.6 & 32.2 & 20.7 & 6.19 \\
\hline & $0.05-0.10$ & 55.8 & 50.2 & 45.0 & 41.4 & 35.7 & 33.8 & 32.6 & 19.8 & \\
\hline & $0.10-0.20$ & 55.4 & 50.0 & 44.5 & 41.5 & 36.4 & 34.4 & 33.4 & 19.6 & \\
\hline & $0.20-0.30$ & 59.2 & 49.7 & 43.7 & 40.1 & 34.8 & 32.7 & 31.9 & 21.5 & \\
\hline \multirow[t]{4}{*}{ Black oat } & $0-0.05$ & 56.6 & 49.4 & 42.4 & 39.1 & 33.3 & 31.2 & 30.2 & 18.8 & 6.00 \\
\hline & $0.05-0.10$ & 53.9 & 49.7 & 43.8 & 40.3 & 35.3 & 33.5 & 32.4 & 19.7 & \\
\hline & $0.10-0.20$ & 55.6 & 50.0 & 43.6 & 40.7 & 35.4 & 34.6 & 33.8 & 19.7 & \\
\hline & $0.20-0.30$ & 57.8 & 50.4 & 43.1 & 39.3 & 33.8 & 31.9 & 30.9 & 20.8 & \\
\hline
\end{tabular}


For most of the rotations there were no significant differences among the water retained at different depths for any of the metric potentials or for maize and soybean plots. However, when the available water holding capacity (AWC) was obtained by integrating water retention values from $0.0-0.30 \mathrm{~m}$ horizons, it varied from 5.43 to $6.38 \mathrm{~cm}$ in maize and from 5.44 to $6.44 \mathrm{~cm}$ in soybean plots. The three best crop rotations that improved this property in maize plots are oat $>$ lathyrus $>$ black oat (Table 5) and in soybean plots (Table 6), wheat $>$ rye $>$ crotalaria. This suggests the predominantly better performance of the grass than legume cover crops in improving this soil physical property. Similar results have been reported in other parts of the tropics ( Lal et al., 1978; 1979) and other states in Brazil (Landers, 2000) and point to the suggested use of grasses (with dense root systems which enhance the availability of water in the rhizosphere) as cover crops.

Effects of crop rotation on aggregate stability of soil: Aggregate stability values for the two crops varied significantly $(\mathrm{p}<0.05)$ within soil horizons and among the crop rotations(Table 7).

\begin{tabular}{|c|c|c|c|c|}
\hline \multirow[t]{2}{*}{ Crops/Treatments } & \multicolumn{4}{|c|}{ Profile depths (m) } \\
\hline & 0-0.05 & 0.05-0.15 & $0.15-0.30$ & Means \\
\hline \multicolumn{5}{|c|}{ Maize } \\
\hline Lupin+Black oat & 2.995 & 1.798 & 1.932 & 2.302 \\
\hline Lupin & 2.262 & 2.071 & 2.215 & 2.183 \\
\hline Rye & 3.146 & 1.938 & 1.609 & 2.231 \\
\hline Oat & 2.119 & 2.183 & 1.548 & 1.950 \\
\hline Lathyrus & 1.906 & 1.939 & 1.689 & 1.845 \\
\hline Wheat & 2.363 & 2.156 & 1.605 & 2.041 \\
\hline Crotalaria & 2.188 & 2.021 & 1.657 & 1.955 \\
\hline Black oat & 2.143 & 1.710 & 1.599 & 1.817 \\
\hline LSD (0.05): Trts (T): & 0.345 & & & \\
\hline Depth (D): & 0.786 & & & \\
\hline TxD: & 0.550 & & & \\
\hline \multicolumn{5}{|c|}{ Soybean } \\
\hline Lupin+Black oat & 2.867 & 1.789 & 1.922 & 2.193 \\
\hline Lupin & 2.301 & 2.063 & 2.204 & 2.189 \\
\hline Rye & 2.997 & 1.982 & 1.607 & 2.195 \\
\hline Oat & 2.101 & 2.139 & 1.549 & 1.930 \\
\hline Lathyrus & 2.010 & 1.908 & 1.692 & 1.870 \\
\hline Wheat & 2.402 & 2.166 & 1.611 & 2.062 \\
\hline Crotalaria & 2.078 & 2.008 & 1.650 & 1.912 \\
\hline Black oat & 2.043 & 1.693 & 1.593 & 1.776 \\
\hline LSD (0.05): Trts (T): & 0.378 & & & \\
\hline Depth (D): & 0.903 & & & \\
\hline TxD & 0.662 & & & \\
\hline
\end{tabular}

Their large values are indicative of the large diameter used $(<9.52 \mathrm{~mm})$ and the controlling influence of other aggregating agents like iron and aluminium oxides, since as will be shown later, the contribution of organic matter to the aggregate stability of this soil is quite low. Taking the average of the two horizons for each of the rotations for maize or soybean, the crops that produced the best aggregate stability values $(>2.000 \mathrm{~mm})$ were the same and varied in the order, rye $>$ lupin+black oat $>$ lupin $>$ wheat. Here the grasses did better than the legumes apparently because they produce more mucilages and gums, which bind the aggregates into stable structures and/or they accumulate more humic susbstances (which are responsible for aggregate stability at the colloidal level) than legumes because of their slower decomposition rates (Piccolo and Mbagwu, 1994; 1999, Mbagwu and Auerswald, 1999).

Effects of crop rotation on saturated hydraulic conductivity of soil: The saturated hydraulic conductivity values (Table 8 ) showed consistent increase from the $0.0-0.15 \mathrm{~m}$ to 0.15 $-0.30 \mathrm{~m}$ depths in all the rotations and the two crops.

Table 8. Effects of crop rotations on saturated hydraulic conductivity ( $\mathrm{m} /$ day) of a Ferralsol under maize and soybean in southern Brazil.

\begin{tabular}{|c|c|c|c|c|c|c|}
\hline \multirow[t]{2}{*}{ Treatments } & \multicolumn{3}{|c|}{$\begin{array}{c}\text { Maize } \\
\text { Profile depths (m) }\end{array}$} & \multicolumn{3}{|c|}{$\begin{array}{c}\text { Soybean } \\
\text { Profile depths (m) }\end{array}$} \\
\hline & $\begin{array}{l}0.0- \\
0.15\end{array}$ & $\begin{array}{l}0.15- \\
0.30\end{array}$ & Means & $\begin{array}{l}0.0- \\
0.15\end{array}$ & $\begin{array}{l}0.15- \\
0.30\end{array}$ & Means \\
\hline Lupin+Black oat & 0.34 & 0.41 & 0.38 & 0.31 & 0.38 & 0.35 \\
\hline Lupin & 0.37 & 0.44 & 0.41 & 0.34 & 0.47 & 0.41 \\
\hline Rye & 0.26 & 0.52 & 0.39 & 0.24 & 0.32 & 0.28 \\
\hline Oat & 0.33 & 0.43 & 0.38 & 0.30 & 0.40 & 0.35 \\
\hline Lathyrus & 0.35 & 0.39 & 0.37 & 0.32 & 0.39 & 0.36 \\
\hline Wheat & 0.27 & 0.30 & 0.29 & 0.23 & 0.31 & 0.27 \\
\hline Crotalaria & 0.35 & 0.37 & 0.36 & 0.31 & 0.40 & 0.36 \\
\hline Black oat & 0.31 & 0.43 & 0.37 & 0.29 & 0.39 & 0.34 \\
\hline $\begin{array}{l}\text { LSD (0.05): Trts } \\
\text { (T): }\end{array}$ & 0.07 & & & 0.08 & & \\
\hline Depth (D): & 0.19 & & & 0.16 & & \\
\hline $\mathrm{TxD}$ & 0.12 & & & 0.09 & & \\
\hline
\end{tabular}

The average values obtained for the horizons showed narrower variability in this property for maize $(9.5 \%)$ than for soybean $(13.3 \%)$. These variations are small for this hydraulic property but may be related to the fact that it was measured in the field and large measurements, five (5) per replicate, were obtained as against those of Mbagwu (1995) and Khan and Afzal (1990) where small core samples $\left(\approx 100 \mathrm{~cm}^{3}\right)$ were used. 
The rotation crops that performed best in maize plots are lupin $>$ rye $>$ oat and lupin+black oat and in soybean, lupin $>$ lathyrus and crotalaria $>$ oat and lupin+black oat. It would have been expected that those rotations that stabilized the aggregates most would also increase the saturated hydraulic conductivity. This was not the case here perhaps because this Ferralsol is very prone to dispersion and the factors that influence its aggregate stability may not be having any controls on its saturated hydraulic conductivity. Also the wide variability in Ksat compared to aggregate stability suggests that different factors may be controlling the two processes.

\section{Effects of crop rotation on organic matter content and relationship between organic matter and physical properties}

The distribution of organic matter (OM) with depth did not follow any consistent pattern among the crop rotations and between maize and soybean plots (Table 9).

Table 9. Effects of crop rotations on organic matter content of a Ferralsol (\%) under maize and soybean in southern Brazil.

\begin{tabular}{lccccc}
\hline Crops/Treatments & \multicolumn{5}{c}{ Profile depths (cm) } \\
\cline { 2 - 6 } & $\mathbf{0 - 5}$ & $\mathbf{5 - 1 0}$ & $\mathbf{1 0 - 2 0}$ & $\mathbf{2 0 - 3 0}$ & Means \\
\hline \multirow{5}{*}{ Maize } & & & \\
Lupin & 4.0 & 3.8 & 4.0 & 4.1 & 4.0 \\
Rye & 3.7 & 3.7 & 3.5 & 3.8 & 3.7 \\
Oat & 3.9 & 3.6 & 3.9 & 3.5 & 3.8 \\
Lathyrus & 3.6 & 3.8 & 3.9 & 3.6 & 3.7 \\
Wheat & 3.8 & 4.0 & 4.2 & 4.1 & 4.0 \\
Crotalaria & 3.7 & 3.7 & 3.9 & 3.7 & 3.8 \\
Black oat & 3.7 & 3.8 & 3.8 & 3.8 & 3.8 \\
LSD (0.05): Trts (T): & 4.1 & 3.9 & 4.1 & 3.7 & 4.0 \\
Depth (D): & 0.42 & & & & \\
TxD: & 0.22 & & & & \\
Lupin+Black oat & 3.6 & 4.1 & 3.9 & 3.8 & 4.0 \\
Lupin & 4.3 & 4.2 & 3.9 & 3.9 & 4.1 \\
Rye & 4.0 & 4.1 & 3.9 & 3.7 & 3.9 \\
Oat & 4.1 & 4.2 & 4.1 & 3.8 & 4.1 \\
Lathyrus & 4.2 & 4.8 & 4.1 & 3.5 & 4.2 \\
Wheat & 4.1 & 3.7 & 3.8 & 3.5 & 3.8 \\
Crotalaria & 4.0 & 3.9 & 3.9 & 3.6 & 3.9 \\
Black oat & 3.9 & 4.1 & 4.0 & 4.1 & 4.0 \\
LSD (0.05): Trts (T): & 0.31 & & & & \\
Depth (D): & 0.83 & & & & \\
TxD: & 0.50 & & & & \\
\hline
\end{tabular}

Also the magnitude of variations in $\mathrm{OM}$ contents with depth for the treatments was low and varied from $1.3 \%$ in crotalaria to $6.3 \%$ in lathyrus plots. The average OM values for the horizons of each crop rotation varied from $3.7 \%$ in lupin, rye and oat plots to $4.1 \%$ in lathyrus treatments in both maize and soybean plots.

Considering that $\mathrm{OM}$ is a moderator of soil physical properties, it is appropriate to evaluate how far changes in this property affected other soil physical properties. It must be pointed out however, that considering the 1985 value of $4.1 \%$ for $\mathrm{OM}$ in this soil, only lathyrus raised OM slightly to $4.2 \%$ after five years of this study. Hence these crop rotations are not effective for building up OM content of this soil in the short-term.

The relationships between soil OM and the measured soil physical properties will enable an evaluation of the extent to which any changes in OM affected them.

As can be seen from Table 10 only the negative relationship between $\mathrm{OM}$ and bulk density in the maize plots was significant.

Table 10. Significant relationships between organic matter and soil physical properties

\begin{tabular}{|c|c|c|c|c|c|}
\hline $\begin{array}{l}\text { Independent } \\
\text { variable }^{1}\end{array}$ & $\begin{array}{l}\text { Dependent } \\
\text { variable }^{2}\end{array}$ & $\begin{array}{l}\alpha \\
\text { (Intercept) }\end{array}$ & $\begin{array}{l}\beta \\
\text { (Slope) }\end{array}$ & $\begin{array}{l}\mathbf{r} \\
\text { (Correlation } \\
\text { coefficient) }^{3}\end{array}$ & $\begin{array}{l}\mathbf{R}^{2} \\
\text { (Coefficient of } \\
\text { determination, } \\
\% \text { ) } \\
\end{array}$ \\
\hline \multicolumn{6}{|c|}{ Maize } \\
\hline \multirow[t]{7}{*}{$\mathrm{OM}$} & $\mathrm{BD}$ & 1.465 & -0.089 & $-0.4340 *$ & 18.8 \\
\hline & TP & 46.019 & 2.972 & $0.3370 \mathrm{NS}$ & 11.4 \\
\hline & $\mathrm{Pe}$ & -1.092 & 3.917 & $0.3098 \mathrm{NS}$ & 9.6 \\
\hline & $\mathrm{Pi}$ & 45.358 & -0.583 & $-0.1927 \mathrm{NS}$ & 3.7 \\
\hline & AWC & 2.558 & 0.264 & $0.2097 \mathrm{NS}$ & 4.4 \\
\hline & MWD & 3.651 & -0.418 & $-0.3712 \mathrm{NS}$ & 13.8 \\
\hline & Ksat & 0.465 & -0.025 & $-0.1138 \mathrm{NS}$ & 1.3 \\
\hline \multicolumn{6}{|c|}{ Soybean } \\
\hline \multirow[t]{7}{*}{$\mathrm{OM}$} & BD & 1.790 & -0.159 & $-0.6022 * *$ & 36.3 \\
\hline & TP & 31.854 & 6.165 & $0.5750 * *$ & 33.1 \\
\hline & $\mathrm{Pe}$ & -26.454 & 9.835 & $0.5852 * *$ & 34.3 \\
\hline & $\mathrm{Pi}$ & 57.122 & -3.379 & $-0.4218^{*}$ & 17.8 \\
\hline & AWC & 1.743 & 0.458 & $0.3166 \mathrm{NS}$ & 10.0 \\
\hline & MWD & 3.717 & -0.427 & $-0.3488 \mathrm{NS}$ & 12.2 \\
\hline & Ksat & -0.558 & 0.225 & $0.6735^{* *}$ & 45.4 \\
\hline
\end{tabular}

${ }^{1} \mathrm{OM}=$ organic matter $(\%)$

${ }^{2} \mathrm{BD}=$ bulk density $(\mathrm{g} / \mathrm{cm} 3) ; \mathrm{TP}=$ total porosity $(\%) ; \mathrm{Pe}=$ macroporosity $(\%) ; \mathrm{Pi}=$ microporosity $(\%)$; AWC = available water holding capacity $(\mathrm{cm}) ; \mathrm{MWD}=$ mean-weight diameter of water-stable aggregates; Ksat $=$ saturated hydraulic conductivity (m/day).

$*$ Significant at $\mathrm{P}<0.05$; ** Significant at $\mathrm{P}<0.01$ : NS $=$ Not significant.

However, the low value of the correlation coefficient $\left(-0.4340^{*}\right)$ shows that not much can be made of this relationship in the physical interpretation of the data. 
On the soybean plots the relationship between $\mathrm{OM}$ and soil physical properties was generally significant. In this highly clay soil (71 $\mathrm{g} \mathrm{kg}^{-1}$ clay) it appears that OM values are not high enough to contribute highly to improvement in its AWC. In other relationships OM explained $17.8 \%$ of variability in $\mathrm{Pi}, 34.3 \%$ in $\mathrm{Pe}, 36.4 \%$ in $\mathrm{BD}, 33.1 \%$ in $\mathrm{TP}$ and $45.4 \%$ in Ksat. These are relatively significant explanations considering the low OM values when compared with their initial (1985) value.

\section{Relationships among soil physical properties}

In the maize plots the relationships among soil physical properties given in Table 11 show that AWC correlated significantly with bulk density, total porosity and macro-porosity.

Table 11. Relationships among some physical properties ${ }^{1}$ (N = 24)

\begin{tabular}{|c|c|c|c|c|c|c|c|c|}
\hline & BD & TP & Pe & $\mathbf{P i}$ & AWC & MWD & Ksat & OM \\
\hline BD & & & & & Maize & & & \\
\hline TP & $-0.908 * *$ & - & & & & & & \\
\hline $\mathrm{Pe}$ & $-0.613 * *$ & $0.627 * *$ & - & & & & & \\
\hline $\mathrm{Pi}$ & $0.338 \mathrm{NS}$ & $-0.226 \mathrm{NS}$ & $-0.591^{* *}$ & - & & & & \\
\hline AWC & $-0.868 * *$ & $0.679 * *$ & $0.690^{* *}$ & $-0.342 \mathrm{NS}$ & - & & & \\
\hline MWD & $-0.274 \mathrm{NS}$ & $0.341 \mathrm{NS}$ & $0.295 \mathrm{NS}$ & $-0.055 \mathrm{NS}$ & $0.362 \mathrm{NS}$ & - & & \\
\hline Ksat & $0.127 \mathrm{NS}$ & $0.067 \mathrm{NS}$ & $0.648^{* *}$ & $-0.191 \mathrm{NS}$ & $0.202 \mathrm{NS}$ & $0.270 \mathrm{NS}$ & - & \\
\hline $\mathrm{OM}$ & $-0.434 *$ & $0.337 \mathrm{NS}$ & $0.310 \mathrm{NS}$ & $-0.193 \mathrm{NS}$ & $0.210 \mathrm{NS}$ & $-0.371 \mathrm{NS}$ & $-0.114 \mathrm{NS}$ & - \\
\hline $\mathrm{BD}$ & 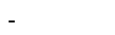 & & & & Soybean & & & \\
\hline TP & $-0.999 * *$ & - & & & & & & \\
\hline $\mathrm{Pe}$ & -0.952 & 0.867 & - & & & & & \\
\hline $\mathrm{Pi}$ & $0.789^{* *}$ & $-0.785 * *$ & $-0.936 * *$ & - & & & & \\
\hline AWC & $-0.321 \mathrm{NS}$ & $0.332 \mathrm{NS}$ & $0.043 \mathrm{NS}$ & $0.295 \mathrm{NS}$ & - & & & \\
\hline MWD & $-0.089 \mathrm{NS}$ & $0.064 \mathrm{NS}$ & $0.059 \mathrm{NS}$ & $0.145 \mathrm{NS}$ & 0.135 & - & & \\
\hline Ksat & $-0.334 \mathrm{NS}$ & $0.406^{*}$ & $0.323 \mathrm{NS}$ & $-0.255 \mathrm{NS}$ & $0.138 \mathrm{NS}$ & $-0.113 \mathrm{NS}$ & & \\
\hline $\mathrm{OM}$ & $-0.602 * *$ & $0.575 * *$ & $0.585^{* *}$ & $-0.422^{*}$ & $0.317 \mathrm{NS}$ & $-0.349 \mathrm{NS}$ & $0.674 * *$ & - \\
\hline
\end{tabular}

The negative relationship between macroand micro-porosity is expected, whereas that between bulk density and macro-porosity implies a reduction in macro-porosity as the soil increases in strength, which should also be expected. The significant and positive correlation between saturated hydraulic conductivity (Ksat) and Pe should also be expected but according to Mbagwu (1995), Smetten and Collis-George (1985) and Franzmeier (1991), the correlation between the two properties was described better by logtransformed than normal Ksat values. Also higher OM in soils reduced their bulk densities as the present study has shown and indicates that OM forms bridges between the soil particles thereby preventing them from parking too closely together.
In the soybean plots the relationships among the bulk density, total, macro- and micro-porosity values where highly significant. Increases in bulk density reduced macroporosity but increased total and microporosities. Also indicated here is that increase in total porosity resulted in a concomitant increase in Ksat but it has already been shown that macro- rather than total porosity accounts for much of the movement of water within the soil (Grismer, 1986; Bouma, 1991). The relationships between $\mathrm{OM}$ and all measured properties but available water holding capacity (AWC) and aggregate stability (MWD) confirm the moderating influence of $\mathrm{OM}$ on soil bulk density and its positive influence on Ksat. It is envisaged that with longer crop production under these rotation systems more influences of $\mathrm{OM}$ on these properties may be expected.

\section{CONCLUSION}

From the results of this study it is evident that on both the maize and soybean plots a combination of lupin and black oat performed best in enhancing the measured physical properties of this soil. This agrees with literature in which combinations of grasses and legumes perform better than either when used alone in crop rotation experiments. Hence it is concluded that this rotation crop is better than the rest of the rotations in enhancing the physical integrity of this Ferralsol.

\section{REFERENCES}

Ahuja, L.R., Gassel, D.K., Bruce, R.R. and Barnes, B.B. 1989. Evaluation of spatial distribution of hydraulic conductivity using effective porosity data. Soil Sci., 148: 404-411.

Alves, M.C., Vieira, S.R., de Castro, O.M. and Lombardi, F. 1994. Effects of crop rotation systems with no tillage on the physical properties of a "Latasol Roxo". 15 $5^{\text {th }}$ World Congress of Soil Science, Acapulco, Mexico, pp. 147-148.

Angers, D.A. and Mehuys, G.R. 1993. Aggregate stability to water. In: Carter, M.R. Ed. Soil Sampling and Methods of Analysis. Can. Soc. Soil Sci., Lewis Publishers, pp. 651-657. 
Ball, B.C. and Hunter, R. 1988. The determination of water release characteristics of soil cores at low suction. Geoderma 43: 195-212.

Blake, G.R. and Hartge, K.H. 1986a. Bulk density. Pages 363-375 in A. Klute, Ed. Methods of Soil Analysis, Part 1, Agronomy No. 9., $2^{\text {nd }}$ ed. ASA., Madison, WI.

Blake, G.R. and Hartge, K.H. 1986b. Particle density. Pages 377-382 in A. Klute, Ed. Methods of Soil Analysis, Part 1, Agronomy No. 9., $2^{\text {nd }}$ ed. ASA., Madison.

Bouma, J. 1991. Influence of soil macroporosity on environmental quality. Adv. Agron. 46: 1-37. Bouma, J. and Hole, F.D. 1971. Soil structure and hydraulic conductivity of adjacent virgin and cultivated pedons at two sites: a Typic Argiudoll (silt loam) and a Typic Eutrochrept (clay). Soil Sci. Soc. Amer. Proc. 35: 314-318.

Carter, M.R. 1988. Temporal variability of soil macroporosity in a fine sandy loam under mouldboard ploughing and direct drilling. Soil Tillage Res. 12: 37-51.

Christensen, B.T. and Johnston, A.E. 1997. Soil organic matter and soil quality. Lessons learned from long term experiments at Askov and Rothamsted. In: Gregorich, A.G., Carter, M.R. (Eds.) Soil Quality for Crop Production and Ecosystems Health. Dev. Soil Sci. Vol. 25. Elseveier, Amsterdam, pp. 399-430.

Corsini, P.C. 1991. Impact of soil degradation on crop production in Brazil. Soil Tillage Res. 20: 353-363.

Danielsen, R.E. and Sutherland, P.L. 1986. Soil porosity. Pages 443-461 in A. Klute, Ed. Methods of Soil Analysis, Part 1, Agronomy No. 9., $2^{\text {nd }}$ ed. ASA., Madison.

Dechen, S.C.F., Vieira, S.R., Lombardi, N.F., de Castro, O.M., Quaggio, J.A. and De Maria, I.C.

1988. Physical characterization of a dark-red Latosol under crop rotation with peanut and maize. In: International Conference on Dryland Farming, 1988, Amarillo/Bushland, Texas, USA; Dept of Agricultural Communications, Texas A\&M University, College Station, 1988. pp. 581-583.

Douglas, J.T. and Goss, M.J. 1982. Stability and organic matter content of surface soil aggregates under different methods of cultivation and in grassland. Soil Tillage Res. 2: 155-175.
FAO, 2000. Soil Conservation and Management for Small Farms-Experiences from the State of Santa Catarina, Brazil. FAO Soils Bulletin 77. FAO: Rome. 66 pp.

Fernāndez-Reuda, Ma.J. and Paz-Gonzālez, A. 1998. Influence of organic matter content on soil physical properties. Cad Lab. Xeol. Laxe 23: 101-120. (in Spanish).

Franzmeier, D.D. 1991. Estimation of hydraulic conductivity from effective porosity data for some Indiana soils. Soil Sci. Soc. Am. J., 55: 1801-1803.

Grismer, M.E. 1986. Pore size distribution and infiltration. Soil Sci. 141: 249-260.

Kay, D.D. 1990. Rates of change of soil structure under different cropping systems. Adv. Soil Sci. 12: $1-41$.

Kemper, B. and Derpsch, R., 1981. Results of studies made in 1978 and 1979 to control erosion by cover crops and no-tillage techniques in Paranā, Brazil. Soil tillage Res. 1: 253-267.

Kemper, W.D. and Rosenau, R.C. 1986. Aggregate stability and size distribution. Pages 425-442 in A. Klute, Ed. Methods of Soil Analysis, Part 1, Agronomy No. 9., $2^{\text {nd }}$ ed. ASA., Madison.

Khan, G.S. and Afzal, T., 1990. Hydraulic characteristics of some important soil series of Pakistan. In: Soil Pyhsics-Application under Stress Environment. Pakistan Agric. Res. Council, Islamabad, pp. 224-237.

Klute, A. 1986. Water retention: laboratory methods. Pages 635-666 in A. Klute, Ed. Methods of Soil Analysis, Part 1, Agronomy No. 9., $2^{\text {nd }}$ ed. ASA., Madison.

Klute, A. and Dirksen, C. 1986. Hydraulic conductivity and diffusivity: laboratory methods. Pages 687-734 in A. Klute, Ed. Methods of Soil Analysis, Part 1, Agronomy No. 9., $2^{\text {nd }}$ ed. ASA., Madison.

Köppen, W., 1936. Das geographische system der climate. Verl. Gebr. Borntraeger, Berlin.

Lal, R. 1974. Role of mulching techniques in tropical soil and water management. Technical Bulletin No.1. International Institute of Tropical Agriculture (IITA), Ibadan, $37 \mathrm{p}$

Lal, R. 1979a. Physical characteristics of soils of the tropics: determination and management. In Lal, R. and Greenland, D.J. (eds.) Soil Physical Properties and Crop Production in the Tropics. John Wiley \& Sons, New York. pp. 7-44. 
Lal, R. 1979b. Physical properties and moisture retention characteristics of some Nigerian soils. Geoderma 21: 209-223.

Lal, R. 1998. Agronomic Impact of Soil Degradation. Pages 459-473 in R. Lal., W.H. Blum., C. Valentine and B.A. Stewart (Eds.) Methods of Assessment of Soil Degradation. Adv. Soil Sci. Boca Ratom, CRC Press.

Lal, R., Wilson, G.F. and Okigbo, B.N. 1978. No-tillage farming after various grasses and leguminouos cover crops in tropical Alfisols. I. Crop performance. Field Crop Res. 1, 71-84.

Lal, R., Wilson, G.F. and Okigbo, B.N. 1979. Changes in properties of an Alfisol produced by various cover crops. Soil Sci. 127, 377-382.

Lal, R. and Stewart, B.A. 1990. Soil degradation: a global threat. In Lal, R., and Stewart, B.A. (Eds.) Adv. Soil Sci. Vol. 11. Springer-Verlag, New York, pp. XIIXIV.

Landers, J.N. 2000. Case study: Zero tillage development in tropical Brazil - the study of a successful NGO activity. Rome. FAO, and Wageningen (Netherlands) Agricultural University.

Mbagwu, J.S.C. (1990). Mulch and tillage effects on water transmission characteristics of an Ultisol and maize yield. Pedologie 40: 155-168.

Mbagwu, J.S.C. 1995. Saturated hydraulic conductivity in relation to physical properties of soils in the Nsukka plains, south eastern Nigeria. Geoderma 68: 51-66.

Mbagwu, J.S.C. and Auerswald, K. (1999). Relationship of percolation stability of soil aggregates to land use, selected properties, structural indices and simulated rainfall erosion. Soil and Tillage Res. 50: 197-206.

Mbagwu, J.S.C., Lal, R. and Scott, T.W. 1983. Physical properties of three soils in southern Nigeria. Soil Sci. 136: 48-55.
Mbagwu, J.S.C., Piccolo, A. and Mbila, M.O. (1993b). Water stability of aggregates of some tropical soils treated with humic substances. Pedologie 43: 261284.

McFarlane, D.J., Howell, M.R., Ryder, A.T. and Orr, G.J. 1992. The effect of agriculturaldevelopment on the physical and hydraulic properties of four western Australian soils. Aust. J. Soil Res. 30: 517-532.

Ortolani, A.A., Camargo, M.P.B de., and Pedro, Jr., M.J. 1995. Normais climatologicas dos agrometeorologicos do Instituto Agronômico: 1. Centro Experimental de Campinas. Bull. 155, Instituto Agronômico, Campinas, SP. pp. 13.

Piccolo, A. and Mbagwu, J.S.C. 1994. Effects of humic substances and surfactants on the stability of two tropical soils. Soil Sci. Soc. Am. J. 58: 950-955.

Piccolo, A. and Mbagwu, J. S. C. 1999. Role of hydrophobic components of soil organic matter on the stability of soil aggregates. Soil Sci. Soc. Am. J. 63: 1801-1810.

Reynolds, W.D. and Elrick, D.E. 1987. Laboratory and numerical

assessment of the Guelph permeameter method. Soil Sci. 144: 282-299.

Smetten, K. R. J. and Collis-George, N. 1985. The influence of cylindrical macropores on steady-state infiltration in a soil under pasture. J. Hydrol. 79: 107114.

Snedecor, G.W. and Cochran, W.G. 1976. Statistical Methods. $6^{\text {th }}$ edn. The Iowa State University Press. Ames, IA. Pp. 593.

Topp, G.C. and Zebchuk, W. 1979. The determination of soil-water desorption curves for soil cores. Can. J. Soil Sci. 59: 19-26. 